\title{
Studies on Color Analysis of Dental Porcelains
}

\section{Effect of Covering Non-precious Alloys with Opaque Porcelain Materials}

\author{
Yoshizo OKAMOTO*, Takashi HORIBE*, Yusuke INOUE*, Tomoji MATSUURA** \\ and Koichi NAGAOKA** \\ *Department of Dental Materials, Fukuoka Dental College, 700 Ta, Sawara-ku Fukuoka 814-01, Japan \\ **2nd Department of Prosthetic Dentistry, Fukuoka Dental College, $700 \mathrm{Ta}$, Sawara-ku Fukuoka 814-01, \\ Japan
}

Received on May 26, 1983

We fixed by firing opaque porcelain materials (Uni bond, Vita VMK 68 Paint-on 88) and margin porcelain materials of varying thicknesses on to non-precious alloys (Bio cast of the Co-Cr system, Uni metal of the Ni-Cr-Be system, and Nichrome bond of the $\mathrm{Ni}-\mathrm{Cr}$ system).

The effect of covering oxide films with porcelain materials is discussed.

Key Words: Color Analysis, Non-precious Alloy, Opaque Porcelain

\section{INTRODUCTION}

The porcelain bond casting crown technique is now the best method for approaching natural tooth color. However many aesthetic problems occur because porcelain bond casting crowns are often used for anterior teeth. For example, there are problems involving color harmony with teeth in the opposite jaw, neighboring teeth, gingiva, and the facial tone. ${ }^{1-11)}$ These problems arise because the color tone of the oxide film on the metal surface varies with different metals used for firing. The oxide film color of precious alloys is gray, and that of non-precious alloys is dark blue or dark green. ${ }^{12}$

Here we report the effect, as evaluated by color analysis, of covering oxide films on non-precious alloys with various thicknesses of porcelain materials by firing.

\section{MATERIALS AND METHODS}

Three kinds of non-precious metal alloys for firing (Bio cast of the $\mathrm{Co}-\mathrm{Cr}$ system, Uni metal of the $\mathrm{Ni}-\mathrm{Cr}-\mathrm{Be}$ system, and Nichrome bond of the $\mathrm{Ni}-\mathrm{Cr}$ system) ${ }^{13)}$ were cast $(10 \mathrm{~mm} \times 10 \mathrm{~mm})$ by the ordinal method (Table 1). The surface of the casting metal was made smooth by sand blast treatment using $25 \mu \mathrm{m}$ particles of aluminum oxide. Only the surface of Bio cast was made smooth by using the bonding agent itself.

Opaque porcelain materials for bonding and margin porcelain materials are shown in Table 2. For opaque porcelain materials, seven specimens of Uni bond and six of Vita VMK 68 Paint-on 88 were used. For margin porcelain material, which is naturally used over fired opaque porcelain materials, it was fired in seven specimens directly on to nonprecious metal surfaces used for firing. The firing schedule for opaque and margin porcelain 
Table 1 Percentage Composition of Non-precious Alloys ${ }^{13)}$

\begin{tabular}{lcccccccccc} 
& $\mathrm{Co}$ & $\mathrm{Cr}$ & $\mathrm{Ni}$ & $\mathrm{Mo}$ & $\mathrm{Si}$ & $\mathrm{Mn}$ & $\mathrm{Al}$ & $\mathrm{Mg}$ & $\mathrm{Be}$ \\
\hline Bio cast & 62.29 & 31.31 & - & 2.57 & 2.42 & 0.84 & - & - & - & - \\
Uni metal & - & 12.62 & 79.33 & 4.75 & - & - & 1.21 & 0.25 & 2.11 \\
Nichrome bond & - & 21.92 & 58.47 & 13.09 & 2.03 & 1.76 & 1.84 & 0.51 & - \\
\hline
\end{tabular}

Table 2 Porcelain and Margin porcelain materials used for firing

\begin{tabular}{|c|c|c|c|c|c|c|}
\hline SHADE & I & Lot No. & II & Lot No. & III & Lot No. \\
\hline A1 & $\mathrm{A}_{1} \mathrm{O}$ & 118018 & 510 & 79 & - & $\longrightarrow$ \\
\hline $\mathrm{A} 2$ & - & $\longrightarrow$ & - & - & $\mathbf{A}_{2} \mathbf{M}$ & 108203 \\
\hline A4 & $\mathrm{A}_{4} \mathrm{O}$ & 108011 & 514 & 928 & $\mathbf{A}_{4} \mathbf{M}$ & 108202 \\
\hline B1 & $\mathrm{B}_{1} \mathrm{O}$ & 118002 & 515 & 705 & $\longrightarrow$ & $\longrightarrow$ \\
\hline B2 & - & $\longrightarrow$ & - & - & $\mathbf{B}_{2} \mathbf{M}$ & 108202 \\
\hline B4 & $\mathrm{B}_{4} \mathrm{O}$ & 108014 & - & - & $\mathrm{B}_{4} \mathbf{M}$ & 078201 \\
\hline $\mathrm{Cl}$ & $\mathrm{C}_{1} \mathrm{O}$ & 108013 & 517 & 790 & - & $\longrightarrow$ \\
\hline $\mathrm{C} 2$ & - & 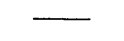 & - & - & $\mathrm{C}_{2} \mathrm{M}$ & 078201 \\
\hline $\mathrm{C} 4$ & $\mathrm{C}_{4} \mathrm{O}$ & 108013 & 519 & 177 & $\mathrm{C}_{4} \mathrm{M}$ & 078201 \\
\hline D2 & - & $\longrightarrow$ & & & $\longrightarrow$ & $\longrightarrow$ \\
\hline D3 & $\mathrm{D}_{3} \mathrm{O}$ & 108015 & 563 & 41 & $\mathrm{D}_{3} \mathrm{M}$ & 078201 \\
\hline
\end{tabular}

materials as suggested by the manufacturers were followed. For color analysis of the samples, the Value (L), Hue (a), and Chroma (b) were measured on R.S. Hunter."

\section{RESULTS AND DISCUSSION}

Figure 1 and Table 3 show the relationship between porcelain thickness and $L$, $a$, and $b$ values when porcelain materials $\mathrm{A}_{1} \mathrm{O}, \mathrm{A}_{4} \mathrm{O}, 510$, and 514 were fired on to the Bio cast. For the $\mathrm{L}$ value, $\mathrm{A}_{4} \mathrm{O}$ was brightest, and 510,514 , and $\mathrm{A}_{1} \mathrm{O}$ were gradually darker in the order given. Especially on the Bio cast, the $L$ value of the alloy surface was 35.44 (3.614) by surface treatment, which is a low value. But $\mathrm{A}_{1} \mathrm{O}$ at a thickness of $0.07 \mathrm{~mm}$ showed a value of 69.76. The a values for $\mathrm{A}_{4} \mathrm{O}$ tended to indicate a slight red color, and the a values for 514 tended to change from slightly green to slightly red as thickness increased. $\mathrm{A}_{1} \mathrm{O}$ tended to show a slight green color, which was different from the others. The $\mathrm{b}$ values tended to indicate a yellow color in all cases.

Figure 2 and Table 4 show the relationship between porcelain thickness and $\mathrm{L}, \mathrm{a}$, and $\mathrm{b}$ values when porcelain materials $\mathrm{B}_{1} \mathrm{O}, \mathrm{B}_{4} \mathrm{O}$, and 515 were fired on to the $\mathrm{Bio}$ cast. For the $\mathrm{L}$ values, at a $0.08 \mathrm{~mm}$ thickness, $\mathrm{B}_{1} \mathrm{O}$ was 69.67 (1.218), 515 was 66.95 (1.309), and $\mathrm{B}_{4} \mathrm{O}$ 

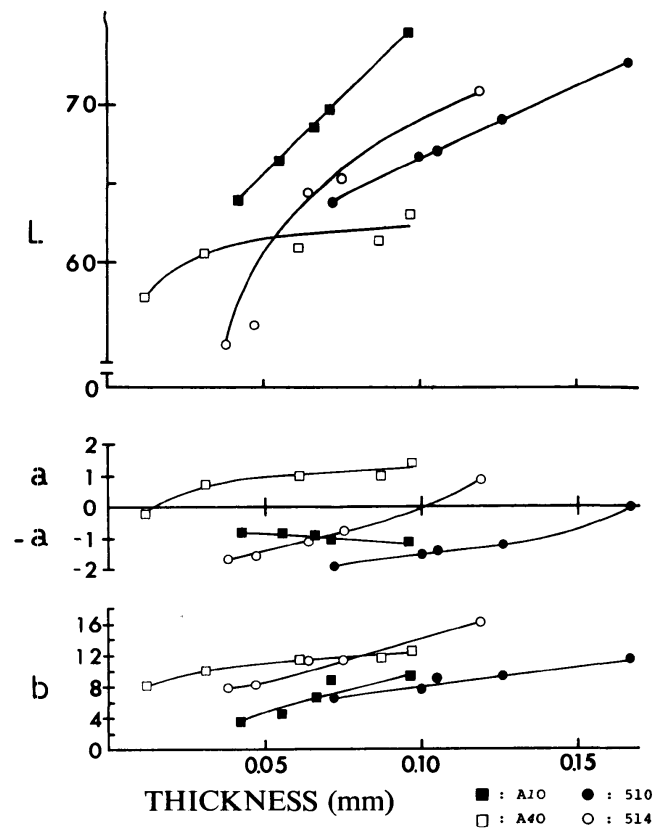

Figure 1 Relationship between porcelain thickness and $L$, a, and $b$ values when $\mathrm{A}_{1} \mathrm{O}, \mathrm{A}_{4} \mathrm{O}$, 510 , and 514 porcelain materials were fired on to the Bio cast alloy.

Table 3 Measured values for $\mathrm{L}$, $\mathrm{a}$, and $\mathrm{b}$ when $\mathrm{A}_{1} \mathrm{O}, \mathrm{A}_{4} \mathrm{O}, 510$, and 514 porcelain materials were fired on to the Bio cast alloy

\begin{tabular}{|c|c|c|c|c|c|c|c|c|c|c|}
\hline A 10 & & & & BI & $C A$ & ST & & & & 510 \\
\hline 64.02 & & & & 74.76 & & & & & & 72.98 \\
\hline$(2.948)$ & $(1.938)$ & $(1.679)$ & $(0.732)$ & $(0.997)$ & & $(1.961)$ & $(1.577)$ & $(1.935)$ & $(0.779)$ & $(1.102)$ \\
\hline-0.83 & -0.89 & -0.95 & -1.02 & -1.17 & & -1.90 & -1.52 & & & -0.04 \\
\hline$(0.190)$ & $(0.080)$ & $(0.100)$ & $(0.071)$ & $(0.062)$ & & $(0.091)$ & $(0.257)$ & $(0.172)$ & $(0.156)$ & $(0.244)$ \\
\hline 3.55 & 4.51 & 6.50 & 8.75 & 9.19 & & 6.53 & 7.82 & 9.16 & 9.48 & 11.57 \\
\hline$(0.629)$ & $(0.352)$ & $(1.077)$ & $(0.483)$ & $(0.560)$ & & $(1.232)$ & $(0.862)$ & $(1.105)$ & $(0.513)$ & $(0.681)$ \\
\hline $\mathrm{A} 4 \mathrm{O}$ & & & & & & & & & & 514 \\
\hline 57.80 & 0.61 & 60.99 & 1.29 & 63.15 & & 54.80 & 56.09 & 64.44 & 65.38 & 70.90 \\
\hline$(3.790)$ & $(1.498)$ & $(1.397)$ & $(1.133)$ & $(0.685)$ & & $(1.920)$ & $(1.132)$ & $(1.490)$ & $(1.707)$ & $(1.082)$ \\
\hline-0.23 & 0.74 & 0.96 & 0.96 & 1.40 & & -1.70 & -1.60 & -1.11 & -0.80 & 0.87 \\
\hline$(0.361)$ & $(0.318)$ & $(0.235)$ & $(0.167)$ & $(0.166)$ & & $(0.098)$ & $(0.109)$ & $(0.138)$ & $(0.160)$ & $(0.191)$ \\
\hline 8.19 & 10.05 & 11.42 & 11.64 & 12.47 & & 7.88 & 8.14 & 11.35 & 11.35 & 16.07 \\
\hline$(1.503)$ & $(1.023)$ & $(0.675)$ & $(0.460)$ & $(0.383)$ & & $(0.416)$ & $(0.430)$ & $(0.578)$ & $(0.639)$ & $(0.504)$ \\
\hline
\end{tabular}

$$
\text { ( ) : } \pm \text { S. D. }
$$

was 65.34 (1.408), indicating a slight green. Especially on $\mathrm{B}_{1} \mathrm{O}$, this tendency was remarkable. The $b$ values tended to indicate a yellow color as porcelain thickness increased in all cases.

Figure 3 and Table 5 show the relationship between porcelain thickness and L, a, and 

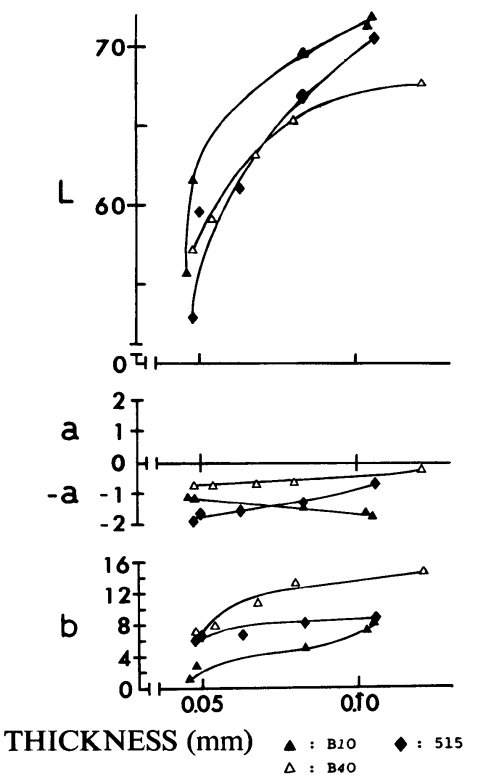

Figure 2 Relationship between porcelain thickness and $\mathrm{L}$, a, and $\mathrm{b}$ values when $\mathrm{B}_{1} \mathrm{O}, \mathrm{B}_{4} \mathrm{O}$, and 515 porcelain materials were fired on to the Bio cast alloy.

Table 4 Measured values for $\mathrm{L}$, $a$, and $\mathrm{b}$ when $\mathrm{B}_{1} \mathrm{O}, \mathrm{B}_{4} \mathrm{O}$, and 515 porcelain materials were fired on to the Bio cast alloy

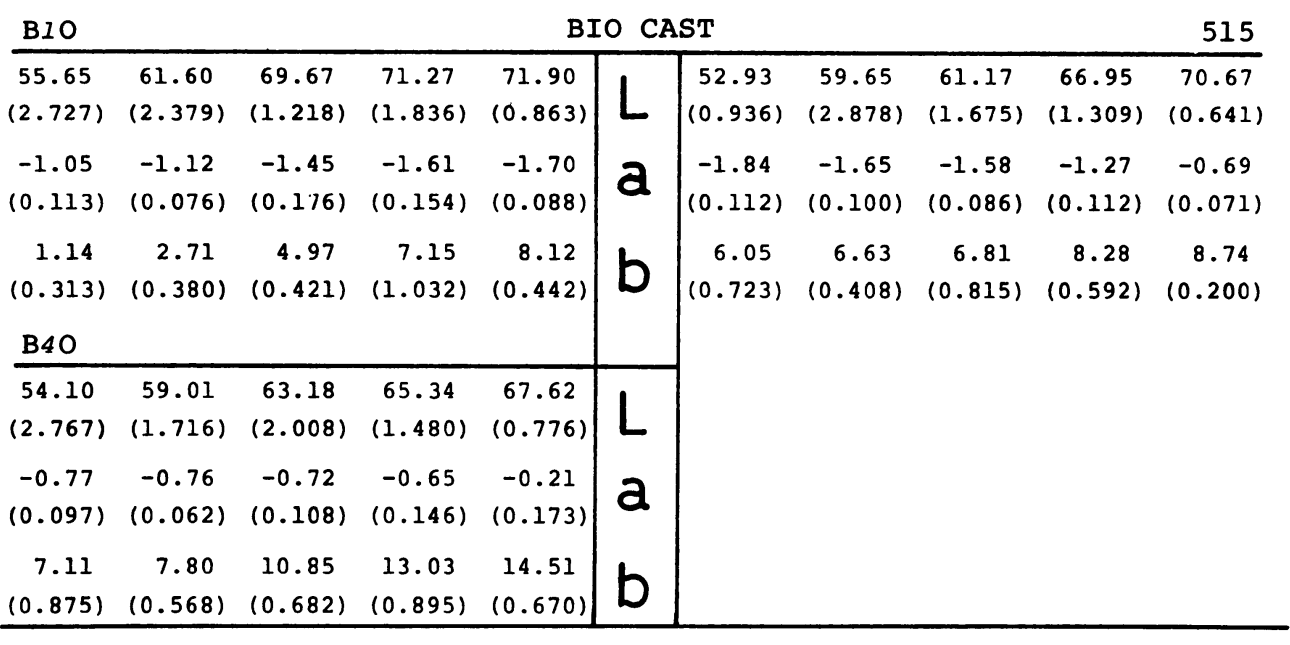

$$
\text { ( ) : } \pm \text { S. D. }
$$

b values when $\mathrm{C}_{1} \mathrm{O}, \mathrm{C}_{4} \mathrm{O}, \mathrm{D}_{3} \mathrm{O}, 517,519$, and 563 were fired on to the Bio cast. Only the values of 563 at thicknesses of $0.05-0.17 \mathrm{~mm}$ were lower than the others. $\mathrm{C}_{4} \mathrm{O}$ tended to be slightly red, and 519 tended to change from slightly green to an achromatic color under thin layer conditions. The $b$ values tended to indicate a yellow color in all cases. 

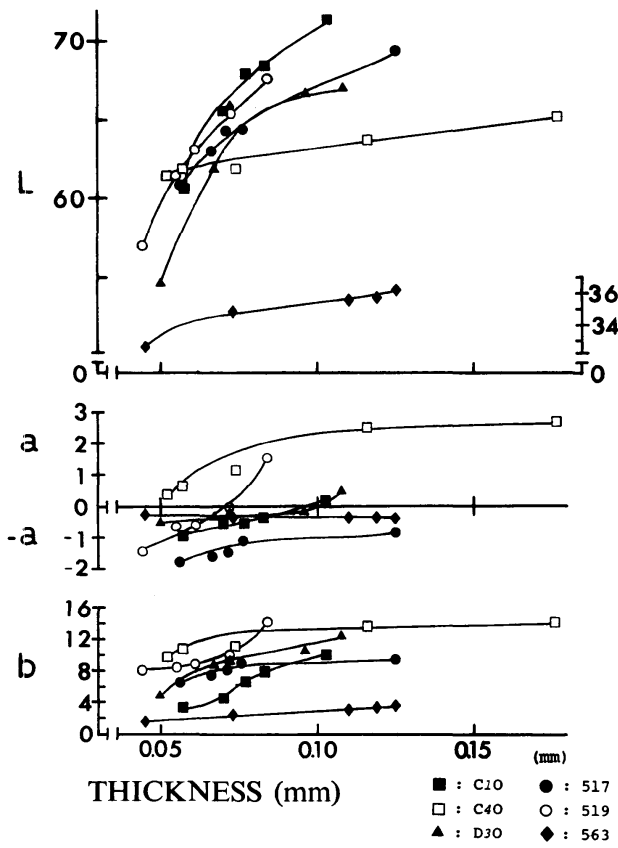

Figure 3 Relationship between porcelain thickness and $\mathrm{L}$, a, and $\mathrm{b}$ values when $\mathrm{C}_{1} \mathrm{O}, \mathrm{C}_{4} \mathrm{O}$, $\mathrm{D}_{3} \mathrm{O}, 517,519$, and 563 porcelain materials were fired on to the Bio cast alloy.

Table 5 Measured values for $\mathrm{L}$, a, and $\mathrm{b}$ when $\mathrm{C}_{1} \mathrm{O}, \mathrm{C}_{4} \mathrm{O}, \mathrm{D}_{3} \mathrm{O}, 517,519$, and 563 porcelain materials were fired on to the Bio cast alloy

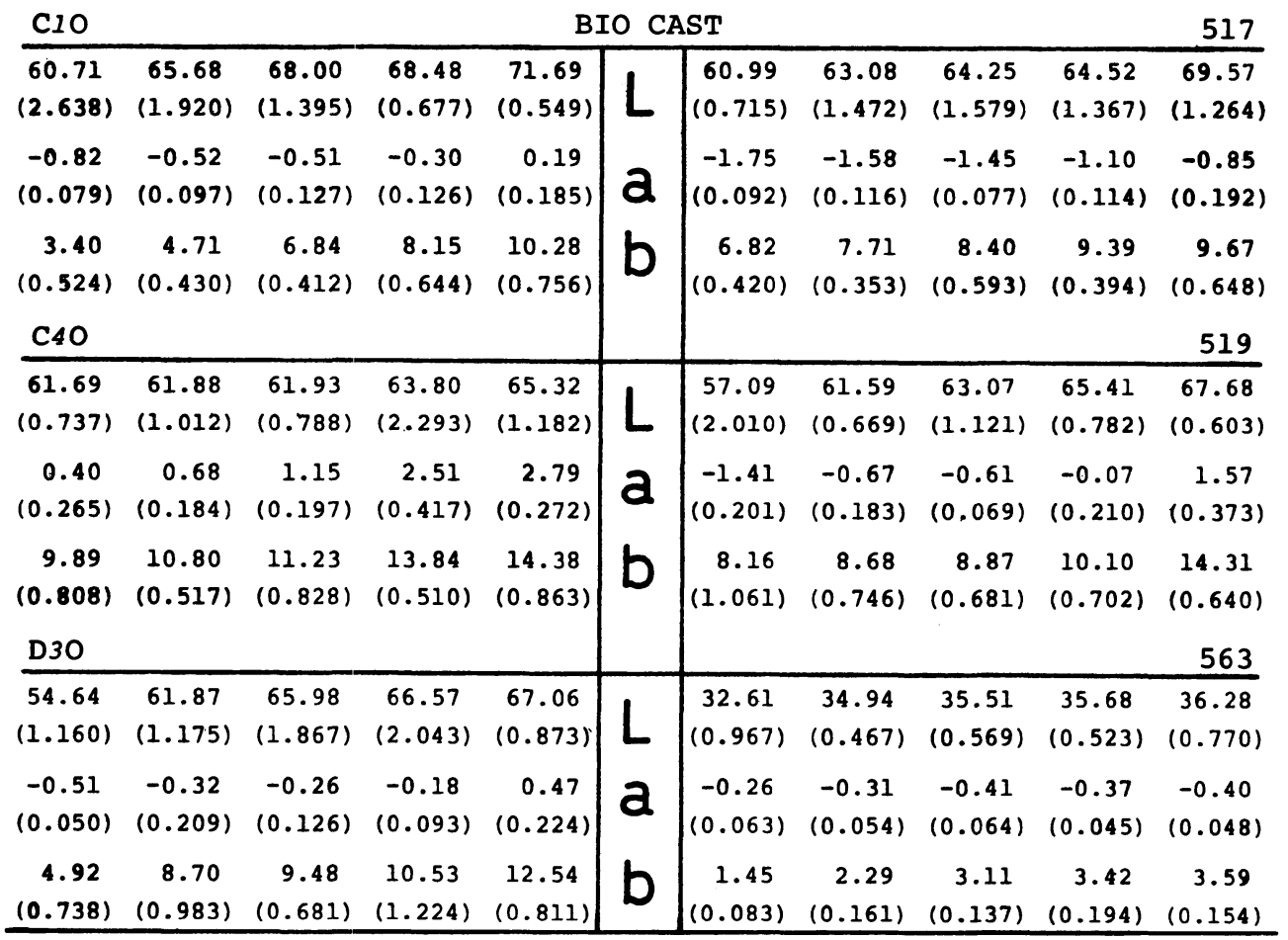




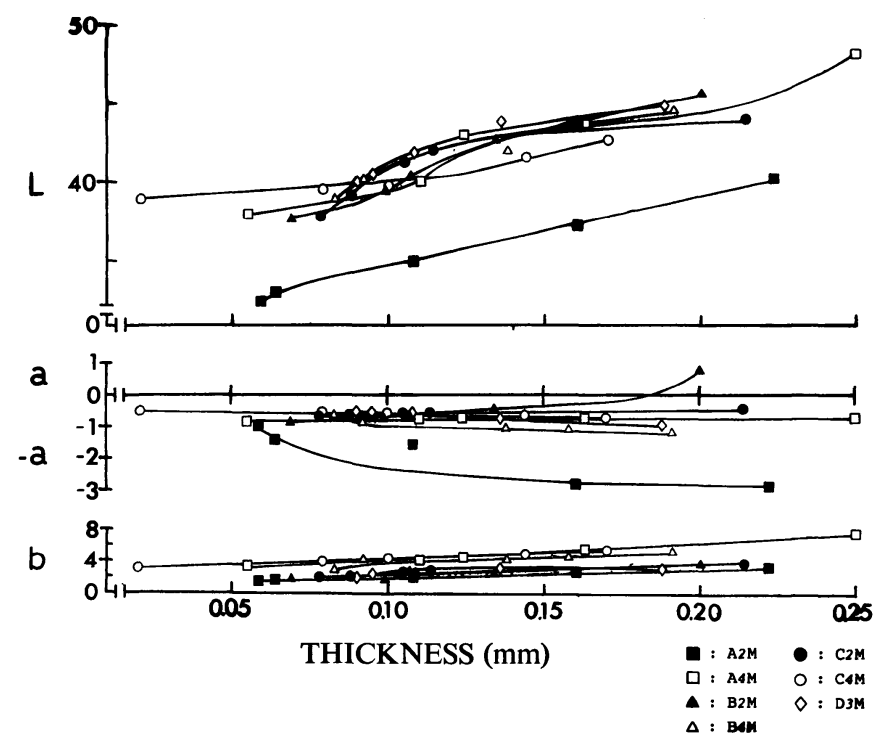

Figure 4 Relationship between porcelain thickness and $L$, $a$, and $b$ values when margin porcelain materials $\left(\mathrm{A}_{2} \mathrm{M}, \mathrm{A}_{4} \mathrm{M}, \mathrm{B}_{2} \mathrm{M}, \mathrm{B}_{4} \mathrm{M}, \mathrm{C}_{2} \mathrm{M}\right.$, $\mathrm{C}_{4} \mathrm{M}$, and $\mathrm{D}_{3} \mathrm{M}$ ) were fired on to the Bio cast alloy.

Figure 4 and Table 6 show the relationship between porcelain thickness and L, a, and $b$ values in seven cases where margin porcelain materials $\left(A_{2} M, A_{4} M, B_{2} M, B_{4} M, C_{2} M, C_{4} M\right.$, and $D_{3} M$ ) were fired on to the Bio cast. The $L$ values, which ranged from $37.71(0.907)$ to $50.18(0.967)$, were generally lower when compared with opaque porcelain materials. For the a value, margin porcelain materials tended toward a slight green color in all cases. Especially $\mathrm{A}_{2} \mathrm{M}$ remarkably showed this tendency.

Figure 5 and Table 7 show the relationship between porcelain thickness and $\mathrm{L}$, a, and $\mathrm{b}$ values when porcelain materials $\left(\mathrm{A}_{1} \mathrm{O}, \mathrm{A}_{4} \mathrm{O}, 510\right.$, and 514) was fired on to Uni metal. The $\mathrm{L}$ value of the Uni metal surface was $47.76(0.182)$. The $\mathrm{L}$ values for $\mathrm{A}_{4} \mathrm{O}$ and 514 were more remarkably changed than those of $\mathrm{A}_{1} \mathrm{O}$ and 510. For the a values, $\mathrm{A}_{1} \mathrm{O}$ tended to indicate a slight green color. 510 and 514 tended to change from slightly red to slightly green, and $\mathrm{A}_{4} \mathrm{O}$ tended toward red. From the $\mathrm{b}$ values, 514 showed $12.46(0.416), \mathrm{A}_{4} \mathrm{O}$ showed 11.62 (1.505), 510 showed 8.29 (0.787), and $\mathrm{A}_{1} \mathrm{O}$ showed $3.05(0.734)$. And each porcelain material tended toward a yellow color.

Figure 6 and Table 8 show the relationship between porcelain thickness and L, a, and $\mathrm{b}$ values when porcelain materials $\mathrm{B}_{1} \mathrm{O}, \mathrm{B}_{4} \mathrm{O}$, and 515 were fired on to Uni metal. An increasing $L$ value with increasing of each porcelain material occurred in all cases. From the a values, each porcelain material tended to be slightly green. Especially $\mathrm{B}_{1} \mathrm{O}$ tended toward green when the porcelain thickness was increased. From the $\mathrm{b}$ values, especially $\mathrm{B}_{4} \mathrm{O}$ tended to show yellow. The $b$ value of $\mathrm{B}_{4} \mathrm{O}$ was $14.05(0.678) ; \mathrm{B}_{1} \mathrm{O}, 8.95(0.739)$; and $515,8.13$ (0.422), and each porcelain tended toward yellow.

Figure 7 and Table 9 show the relationship between porcelain thickness and L, a, and b values when porcelain materials $\mathrm{C}_{1} \mathrm{O}, \mathrm{C}_{4} \mathrm{O}, \mathrm{D}_{3} \mathrm{O}, 517,519$, and 563 were fired on to Uni 
Table 6 Measured values for $L$, $a$, and $b$ when margin porcelain materials $\left(A_{2} M, A_{4} M, B_{2} M\right.$, $\mathrm{B}_{4} \mathrm{M}, \mathrm{C}_{2} \mathrm{M}, \mathrm{C}_{4} \mathrm{M}$, and $\mathrm{D}_{3} \mathrm{M}$ ) were fired on to the Bio cast alloy

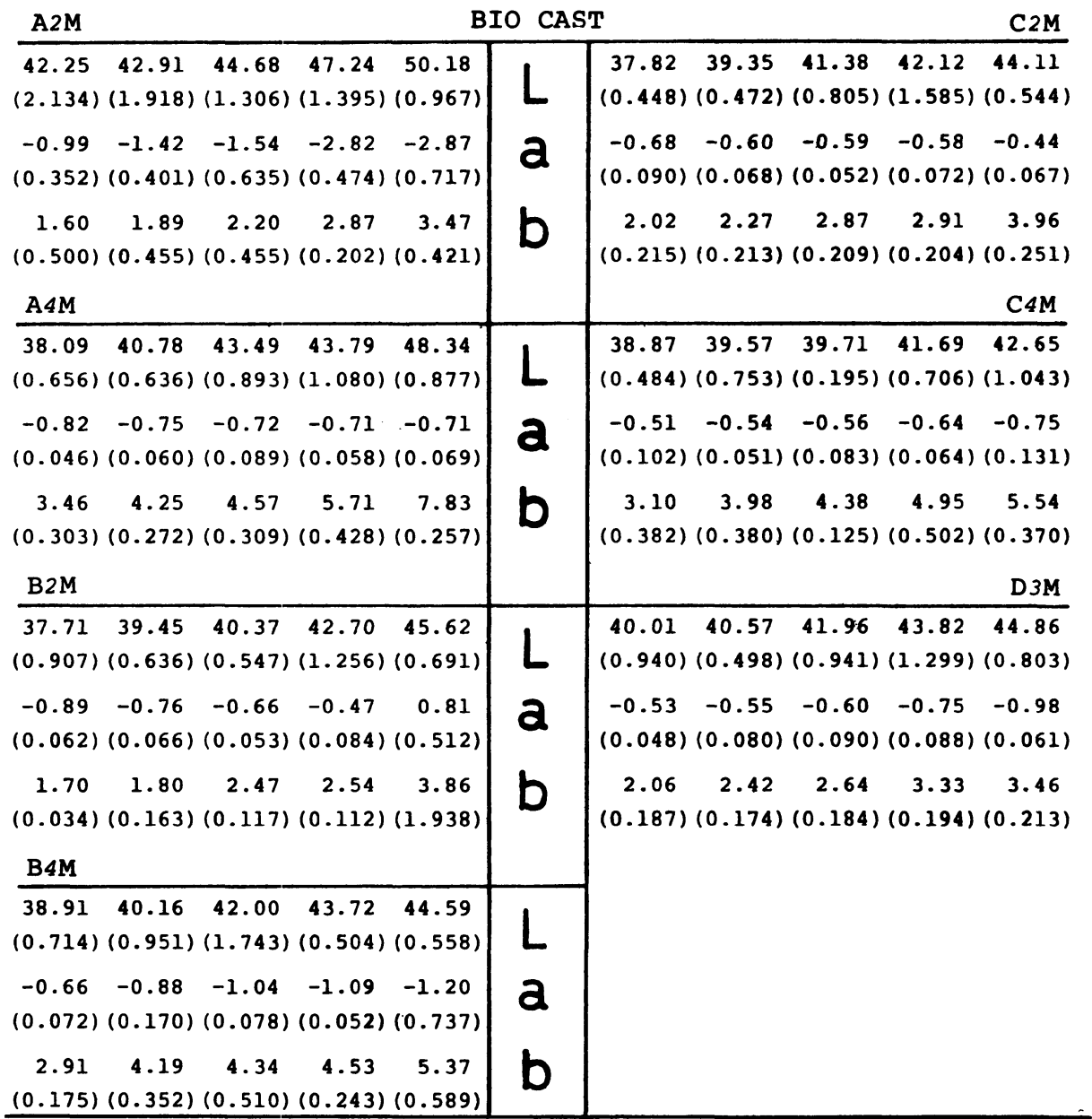

$$
\text { ( ) : } \pm \text { S. D. }
$$

metal. The $\mathrm{L}$ values for 563 ranged from $35.31(0.717)$ to $39.20(1.573)$ at thicknesses from 0.05 to $0.91 \mathrm{~mm}$. These low values were identical to those when 563 was fired on to the Bio cast. The a value for $\mathrm{C}_{4} \mathrm{O}$ strongly indicated a red color at a $0.09 \mathrm{~mm}$ thickness. 563 tended to change from slightly red to slightly green, and the others showed the opposite tendency.

Figure 8 and Table 10 show the relationship between porcelain thickness and L, a, and $b$ values when margin porcelain materials were fired on to Uni metal. The $L$ values for $A_{2} M$ and $\mathrm{B}_{4} \mathrm{M}$ tended to remarkably change with increasing thickness when compared with the others. From a and $b$ values, it appeared that there were no remarkable changes among margin porcelain materials.

Figure 9 and Table 11 show the relationship between porcelain thickness and $\mathrm{L}$, a, and $b$ values when porcelain materials $\mathrm{A}_{1} \mathrm{O}, \mathrm{A}_{4} \mathrm{O}, 510$, and 514 were fired on to the Nichrome 

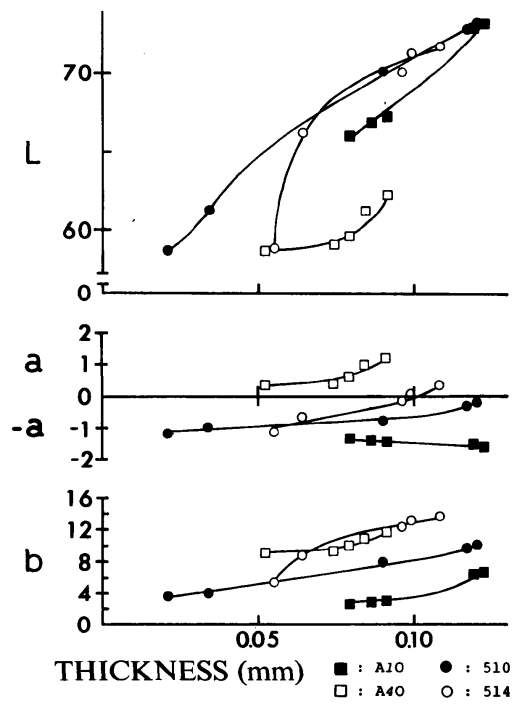

Figure 5 Relationship between porcelain thickness and $L$, $a$, and $b$ values when $A_{1} O, A_{4} O$, 510 , and 514 porcelain materials were fired on to the Uni metal alloy.

Table 7 Measured values of $\mathrm{L}$, a, and $\mathrm{b}$ when $\mathrm{A}_{1} \mathrm{O}, \mathrm{A}_{4} \mathrm{O}, 510$, and 514 porcelain materials were fired on to the Uni metal alloy

\begin{tabular}{|c|c|c|c|c|c|c|c|c|c|c|}
\hline \multicolumn{2}{|l|}{ AlO } & \multicolumn{8}{|c|}{ UNI METAL } & \multirow{2}{*}{$\frac{510}{73.31}$} \\
\hline 66.14 & 66.94 & 67.34 & 73.24 & 73.30 & & 58.71 & 61.35 & & 73.03 & \\
\hline$(3.942)$ & $(1.147)$ & $(2.968)$ & $(2.273)$ & $(1.168)$ & & $(2.176)$ & $(2.333)$ & $(0.793)$ & $(1.461)$ & $(0.671)$ \\
\hline-1.36 & -1.37 & -1.41 & -1.50 & -1.55 & & -1.17 & -0.95 & -0.76 & -0.31 & -0.19 \\
\hline$(0.178)$ & $(0.071)$ & $(0.057)$ & $(0.070)$ & $(0.059)$ & & $(0.146)$ & $(0.352)$ & $(0.121)$ & $(0.269)$ & $(0.205)$ \\
\hline 2.48 & 2.99 & 3.05 & 6.50 & 6.65 & & 3.69 & 4.06 & 8.29 & 9.97 & 10.25 \\
\hline$(0.539)$ & $(0.761)$ & $(0.734)$ & $(1.418)$ & $(1.415)$ & & $(0.656)$ & $(0.643)$ & $(0.787)$ & $(1.011)$ & $(0.397)$ \\
\hline $\mathrm{A} 40$ & & & & & & & & & & 514 \\
\hline 58.58 & 59.06 & 59.61 & 61.27 & 62.27 & & 58.84 & 66.25 & 70.06 & 71.42 & 71.82 \\
\hline$(1.076)$ & $(2.629)$ & $(1.845)$ & $(1.550)$ & $(1.001)$ & & $(2.700)$ & $(2.451)$ & $(0.527)$ & $(1.520)$ & $(1.246)$ \\
\hline 0.33 & 0.39 & 0.61 & 0.99 & 1.40 & & -1.11 & -0.65 & -0.14 & 0.08 & 0.36 \\
\hline$(0.263)$ & $(0.282)$ & $(0.287)$ & $(0.348)$ & $(0.592)$ & & $(0.092)$ & $(0.146)$ & $(0.111)$ & $(0.380)$ & $(0.317)$ \\
\hline 9.05 & 9.23 & 10.03 & 10.93 & 11.62 & & 5.60 & 8.79 & 12.46 & 13.16 & 13.62 \\
\hline$(1.240)$ & $(1.146)$ & $(1.081)$ & $(1.307)$ & $(1.505)$ & & $(0.976)$ & $(0.718)$ & $(0.416)$ & $(1.342)$ & $(0.978)$ \\
\hline
\end{tabular}

$(\quad): \pm$ S. D.

bond. The $\mathrm{L}$ value of the Nichrome bond surface was $49.40(0.311)$. The $\mathrm{L}$ values for 514 ranged from $53.69(1.633)$ to $64.78(0.973)$ at thicknesses from 0.06 to $0.07 \mathrm{~mm}$, the changes in $\mathrm{L}$ values were remarkable. From the a values, $\mathrm{A}_{4} \mathrm{O}$ tended to be slightly red; $\mathrm{A}_{1} \mathrm{O}$, slightly green; and 514 , changed from slightly green to non-hue at a $0.10 \mathrm{~mm}$ thickness.

Figure 10 and Table 12 show the relationship between porcelain thickness and $\mathrm{L}, \mathrm{a}$, and $b$ values when porcelain materials $\mathrm{B}_{1} \mathrm{O}, \mathrm{B}_{4} \mathrm{O}$, and 515 were fired on to the Nichrome bond. The $\mathrm{L}$ value of the $\mathrm{B}_{1} \mathrm{O}$ porcelain material tended to change more than those of $\mathrm{B}_{4} \mathrm{O}$ 

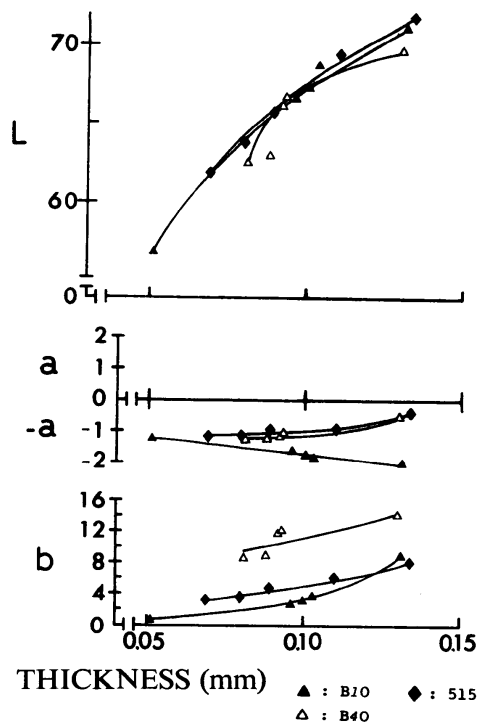

Figure 6 Relationship between porcelain thickness and $L$, a, and $b$ values when $\mathrm{B}_{1} \mathrm{O}$, $\mathrm{B}_{4} \mathrm{O}$, and 515 porcelain materials were fired on to the Uni metal alloy.

Table 8 Measured values for $\mathrm{L}$, $\mathrm{a}$, and $\mathrm{b}$ when $\mathrm{B}_{1} \mathrm{O}, \mathrm{B}_{4} \mathrm{O}$, and 515 porcelain materials were fired on to the Uni metal alloy

\begin{tabular}{|c|c|c|c|c|c|c|c|c|c|c|}
\hline \multicolumn{2}{|l|}{ B1O } & \multicolumn{8}{|c|}{ UNI METAL } & \multirow{2}{*}{$\frac{515}{71.86}$} \\
\hline 56.81 & 66.67 & 67.91 & 68.63 & 71.69 & & 61.84 & 63.94 & 65.76 & 69.42 & \\
\hline$(1.928)$ & $(2.833)$ & $(1.892)$ & $(0.832)$ & $(0.626)$ & & $(0.967)$ & $(1.352)$ & $(0.659)$ & $(0.591)$ & $(1.015)$ \\
\hline-1.22 & -1.67 & -1.72 & -1.88 & -2.05 & & -1.13 & -1.11 & -0.97 & -0.95 & -0.41 \\
\hline$(0.113)$ & $(0.141)$ & $(0.089)$ & $(0.083)$ & $(0.126)$ & & $(0.058)$ & $(0.051)$ & $(0.029)$ & $(0.037)$ & $(0.147)$ \\
\hline 0.54 & 2.58 & 3.04 & 3.53 & 8.95 & & 3.32 & 3.56 & 4.72 & 6.17 & 8.13 \\
\hline$(0.127)$ & $(0.322)$ & $(0.803)$ & $(0.443)$ & $(0.739)$ & & $(0.230)$ & $(0.356)$ & $(0.305)$ & $(0.244)$ & $(0.422)$ \\
\hline \multicolumn{11}{|l|}{$\mathrm{B} 40$} \\
\hline 62.54 & 62.99 & 66.17 & 66.71 & 69.70 & & & & & & \\
\hline$(1.802)$ & $(2.325)$ & $(1.241)$ & $(1.690)$ & $(1.086)$ & & & & & & \\
\hline-1.29 & -1.28 & -1.15 & -1.08 & -0.52 & & & & & & \\
\hline$(0.081)$ & $(0.079)$ & $(0.157)$ & $(0.176)$ & $(0.224)$ & & & & & & \\
\hline 8.57 & 8.90 & 11.84 & 12.36 & 14.05 & & & & & & \\
\hline$(0.414)$ & $(1.299)$ & $(0.934)$ & $(0.856)$ & $(0.678)$ & & & & & & \\
\hline
\end{tabular}

$$
\text { ( ) : } \pm \text { S. D. }
$$

and 515. The $\mathrm{L}$ value for $\mathrm{B}_{1} \mathrm{O}$ ranged from $62.14(1.857)$ to $75.63(0.876)$ at thicknesses from 0.07 to $0.13 \mathrm{~mm}$.

The a values for $\mathrm{B}_{1} \mathrm{O}, \mathrm{B}_{4} \mathrm{O}$, and 515 porcelain materials tended to indicate colors from slightly green to non-hue. The $b$ values for each porcelain tended toward yellow in all cases.

Figure 11 and Table 13 show the relationship between porcelain thickness and L, a, and $\mathrm{b}$ values when porcelain materials $\mathrm{C}_{1} \mathrm{O}, \mathrm{C}_{4} \mathrm{O}, \mathrm{D}_{3} \mathrm{O}, 517,519$, and 563 were fired on to the Nichrome bond. The $\mathrm{L}$ values for 563 tended to be lower than the others $\left(\mathrm{C}_{1} \mathrm{O}, \mathrm{C}_{4} \mathrm{O}\right.$, 

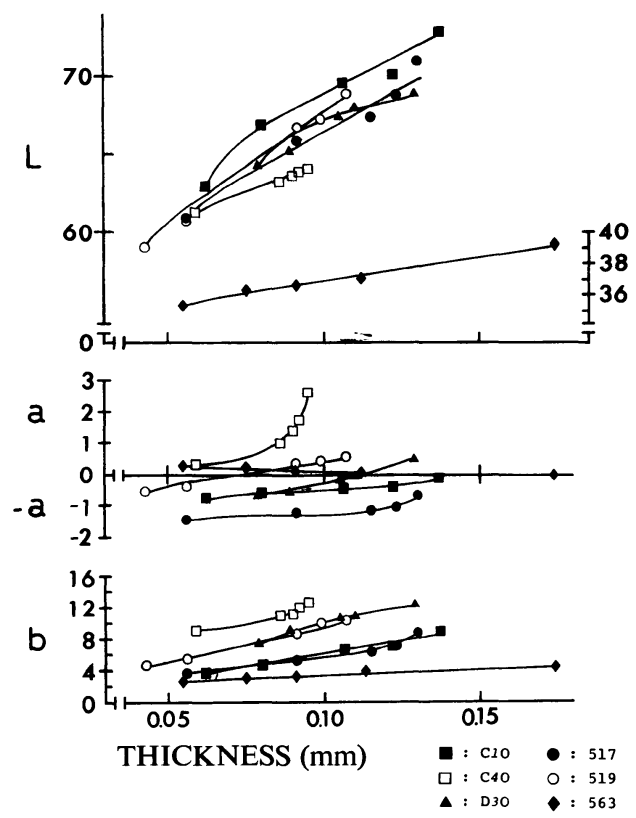

Figure 7 Relationship between porcelain thickness and $\mathrm{L}$, a, and $\mathrm{b}$ values when $\mathrm{C}_{1} \mathrm{O}, \mathrm{C}_{4} \mathrm{O}$, $\mathrm{D}_{3} \mathrm{O}, 517,519$, and 563 porcelain materials were fired on to the Uni metal alloy.

Table 9 Measured values for $\mathrm{L}$, a, and $\mathrm{b}$ when $\mathrm{C}_{1} \mathrm{O}, \mathrm{C}_{4} \mathrm{O}, \mathrm{D}_{3} \mathrm{O}, 517,519$, and 563 porcelain materials were fired on to the Uni metal alloy

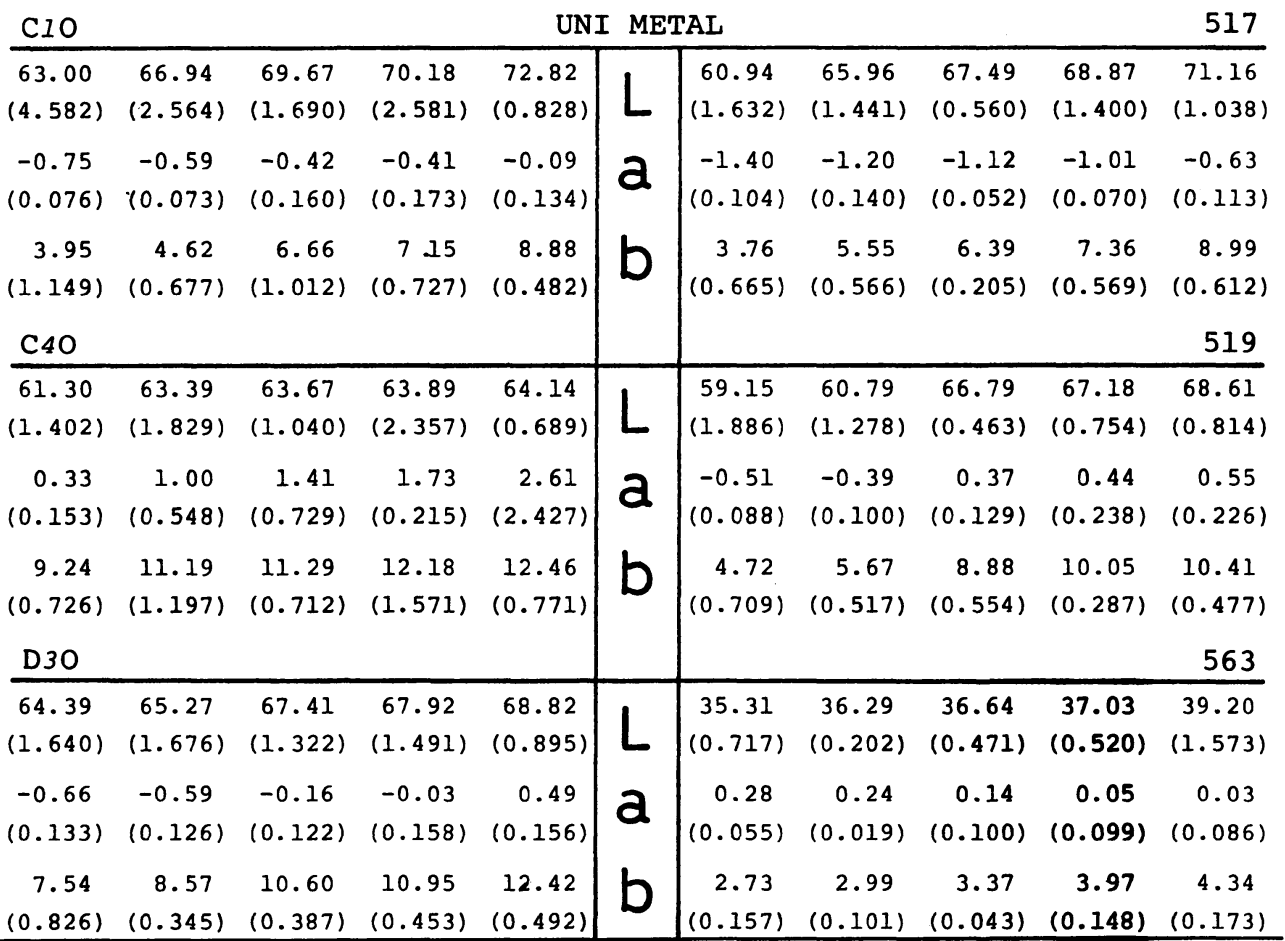

$$
\text { ( ) : } \pm \text { S. D. }
$$




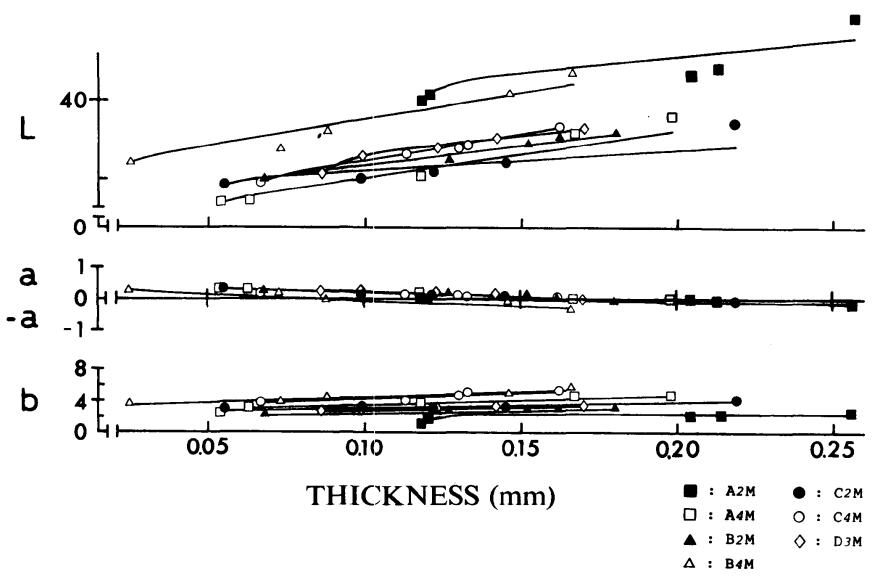

Figure 8 Relationship between porcelain thickness and $\mathrm{L}$, $\mathrm{a}$, and $\mathrm{b}$ values when margin porcelain materials $\left(\mathrm{A}_{2} \mathrm{M}, \mathrm{A}_{4} \mathrm{M}, \mathrm{B}_{2} \mathrm{M}\right.$, $\mathrm{B}_{4} \mathrm{M}, \mathrm{C}_{2} \mathrm{M}, \mathrm{C}_{4} \mathrm{M}$, and $\mathrm{D}_{3} \mathrm{M}$ ) were fired on to the Uni metal alloy.

Table 10 Measured values for $L$, $a$, and $b$ when margin porcelain materials $\left(A_{2} M, A_{4} M, B_{2} M\right.$, $\mathrm{B}_{4} \mathrm{M}, \mathrm{C}_{2} \mathrm{M}, \mathrm{C}_{4} \mathrm{M}$, and $\mathrm{D}_{3} \mathrm{M}$ ) were fired on to the Uni metal alloy

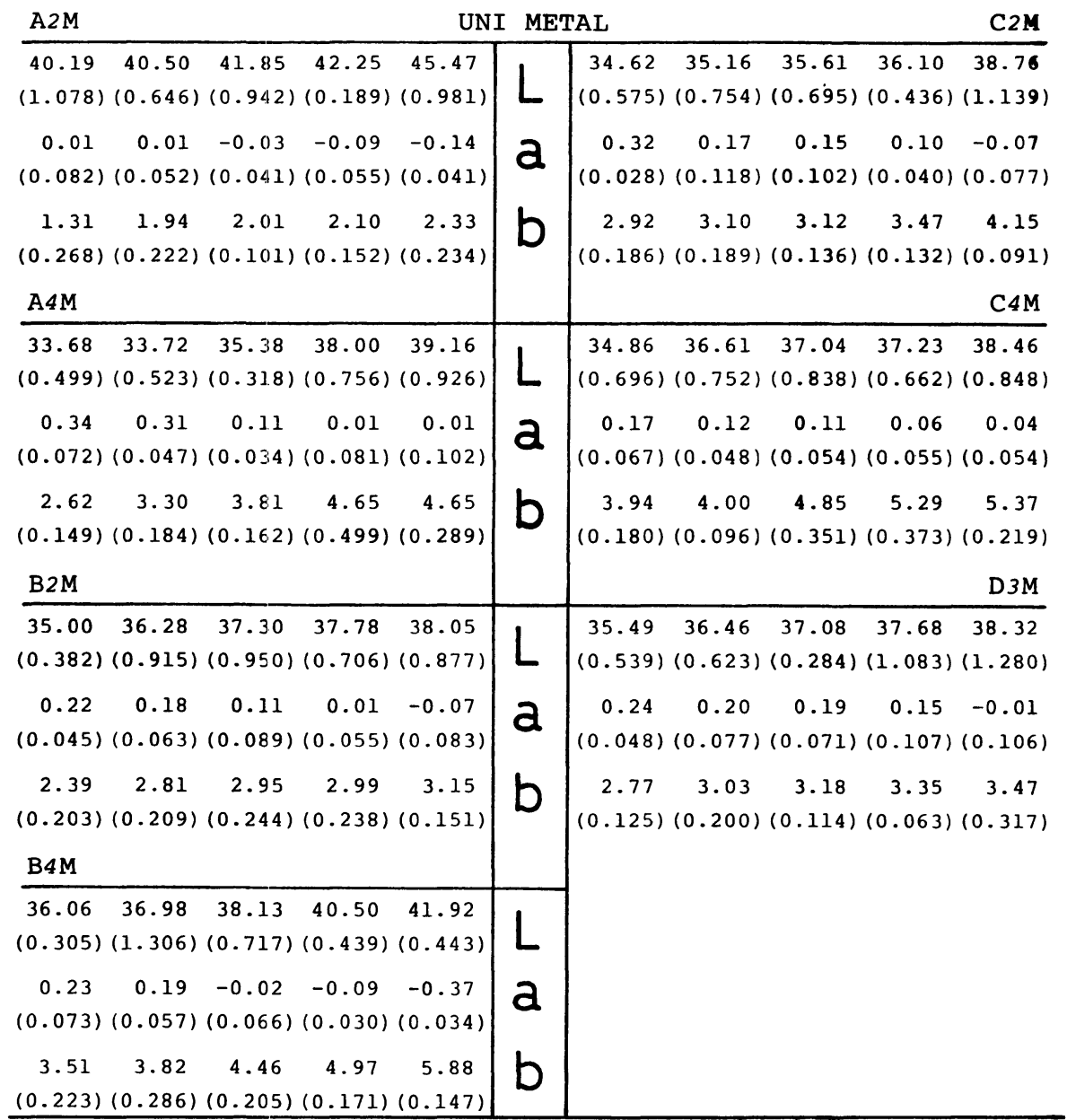




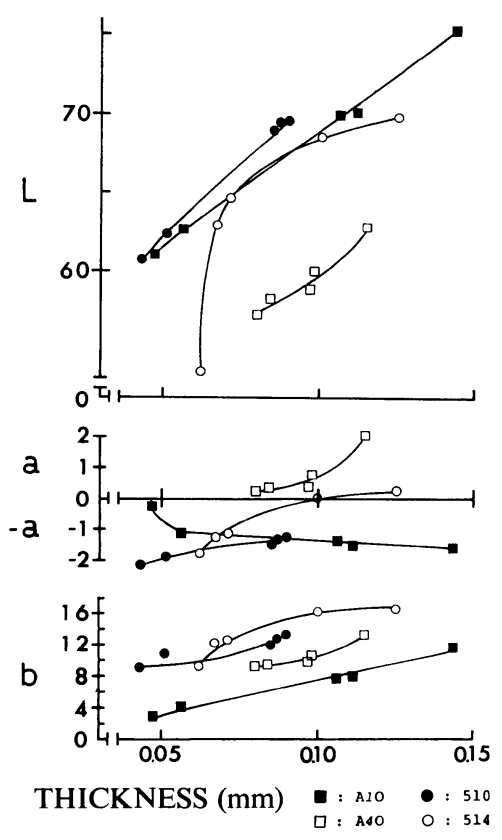

Figure 9 Relationship between porcelain thickness and $\mathrm{L}$, $\mathrm{a}$, and $\mathrm{b}$ values when $\mathrm{A}_{1} \mathrm{O}, \mathrm{A}_{4} \mathrm{O}$, 510 , and 514 porcelain materials were fired on to the Nichrome bond alloy.

Table 11 Measured values for $\mathrm{L}$, a, and $\mathrm{b}$ when $\mathrm{A}_{1} \mathrm{O}, \mathrm{A}_{4} \mathrm{O}, 510$, and 514 porcelain materials were fired on to the Nichrome bond alloy

\begin{tabular}{|c|c|c|c|c|c|c|c|c|c|c|}
\hline AlO & & & & $\mathrm{NICH}$ & & BOND & & & & 510 \\
\hline $\begin{array}{c}61.02 \\
(1.091)\end{array}$ & $\begin{array}{c}62.77 \\
(2.039)\end{array}$ & $\begin{array}{c}70.35 \\
(1.103)\end{array}$ & $\begin{array}{c}70.53 \\
(2.044)\end{array}$ & $\begin{array}{c}75.57 \\
(0.970)\end{array}$ & & $\begin{array}{c}60.81 \\
(1.009)\end{array}$ & $\begin{array}{c}62.41 \\
(1.741)\end{array}$ & $\begin{array}{c}69.02 \\
(0.419)\end{array}$ & $\begin{array}{c}69.56 \\
(0.558)\end{array}$ & $\begin{array}{c}69.59 \\
(0.353)\end{array}$ \\
\hline $\begin{array}{c}-0.26 \\
(0.260)\end{array}$ & $\begin{array}{c}-1.14 \\
(0.070)\end{array}$ & $\begin{array}{c}-1.32 \\
(0.086)\end{array}$ & $\begin{array}{c}-1.47 \\
(0.061)\end{array}$ & $\begin{array}{c}-1.56 \\
(0.114)\end{array}$ & & $\begin{array}{c}-2.11 \\
(0.052)\end{array}$ & $\begin{array}{c}-1.82 \\
(0.113)\end{array}$ & $\begin{array}{c}-1.42 \\
(0.123)\end{array}$ & $\begin{array}{c}-1.30 \\
(0.036)\end{array}$ & $\begin{array}{c}-1.21 \\
(0.070)\end{array}$ \\
\hline $\begin{array}{r}3.08 \\
(0.205) \\
\text { A40 }\end{array}$ & $\begin{array}{c}4.19 \\
(0.645)\end{array}$ & $\begin{array}{c}7.73 \\
(0.456)\end{array}$ & $\begin{array}{c}7.85 \\
(0.852)\end{array}$ & $\begin{array}{c}11.52 \\
(0.474)\end{array}$ & & $\begin{array}{c}9.28 \\
(0.662)\end{array}$ & $\begin{array}{c}11.00 \\
(0.204)\end{array}$ & $\begin{array}{c}12.13 \\
(0.461)\end{array}$ & $\begin{array}{c}13.07 \\
(0.091)\end{array}$ & $\begin{array}{r}13.63 \\
(0.206) \\
514\end{array}$ \\
\hline $\begin{array}{c}57.30 \\
(1.662)\end{array}$ & $\begin{array}{c}58.31 \\
(2.024)\end{array}$ & $\begin{array}{c}58.83 \\
(1.854)\end{array}$ & $\begin{array}{c}60.35 \\
(0.844)\end{array}$ & $\begin{array}{c}62.96 \\
(1.150)\end{array}$ & & $\begin{array}{c}53.69 \\
(1.633)\end{array}$ & $\begin{array}{c}63.06 \\
(1.417)\end{array}$ & $\begin{array}{c}64.78 \\
(0.973)\end{array}$ & $\begin{array}{c}68.60 \\
(0.699)\end{array}$ & $\begin{array}{c}69.93 \\
(1.402)\end{array}$ \\
\hline $\begin{array}{c}0.24 \\
(0.216)\end{array}$ & $\begin{array}{c}0.34 \\
(0.450)\end{array}$ & $\begin{array}{c}0.36 \\
(0.298)\end{array}$ & $\begin{array}{c}0.76 \\
(0.239)\end{array}$ & $\begin{array}{c}2.04 \\
(0.226)\end{array}$ & & $\begin{array}{c}-1.74 \\
(0.055)\end{array}$ & $\begin{array}{c}-1.18 \\
(0.194)\end{array}$ & $\begin{array}{c}-1.14 \\
(0.113)\end{array}$ & $\begin{array}{c}0.06 \\
(0.391)\end{array}$ & $\begin{array}{c}0.28 \\
(0.311)\end{array}$ \\
\hline $\begin{array}{c}9.31 \\
(1.363)\end{array}$ & $\begin{array}{c}9.47 \\
(0.958)\end{array}$ & $\begin{array}{c}9.74 \\
(1.171)\end{array}$ & $\begin{array}{c}10.84 \\
(0.673)\end{array}$ & $\begin{array}{c}13.44 \\
(0.316)\end{array}$ & & $\begin{array}{c}9.44 \\
(0.791)\end{array}$ & $\begin{array}{c}12.48 \\
(1.082)\end{array}$ & $\begin{array}{c}12.70 \\
(0.667)\end{array}$ & $\begin{array}{c}16.04 \\
(1.196)\end{array}$ & $\begin{array}{c}16.69 \\
(0.827)\end{array}$ \\
\hline
\end{tabular}

( ) : \pm S. D.

$\mathrm{D}_{3} \mathrm{O}, 517$, and 519), which were similar to the case when the Bio cast and Uni metal were used. The a values indicated that only 563 tended to become slightly green as porcelain thickness was increased. The $\mathrm{b}$ values for all porcelain materials except 563 indicated yellow. 563 showed no remarkable change even when the porcelain thickness was increased.

Figure 12 and Table 14 show the relationship between porcelain thickness and L, a, 


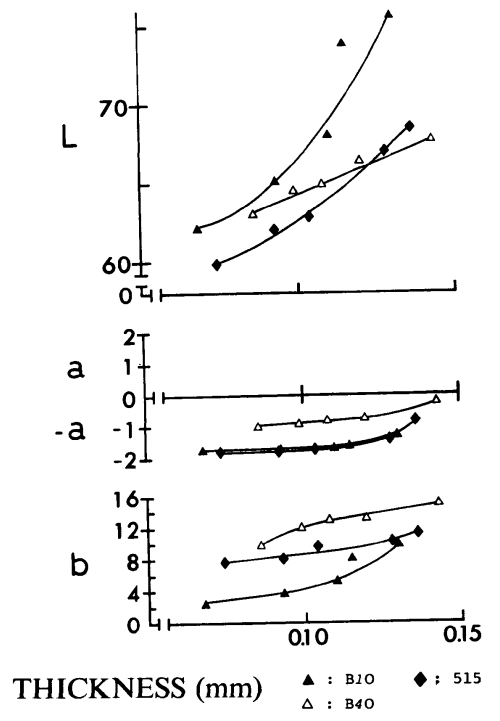

Figure 10 Relationship between porcelain thickness and $\mathrm{L}$, a, and $\mathrm{b}$ values when $\mathrm{B}_{1} \mathrm{O}, \mathrm{B}_{4} \mathrm{O}$, and 515 porcelain materials were fired on to the Nichrome bond alloy.

Table 12 Measured values for $\mathrm{L}$, $\mathrm{a}$, and $\mathrm{b}$ when $\mathrm{B}_{1} \mathrm{O}, \mathrm{B}_{4} \mathrm{O}$, and 515 porcelain materials were fired on to the Nichrome bond alloy

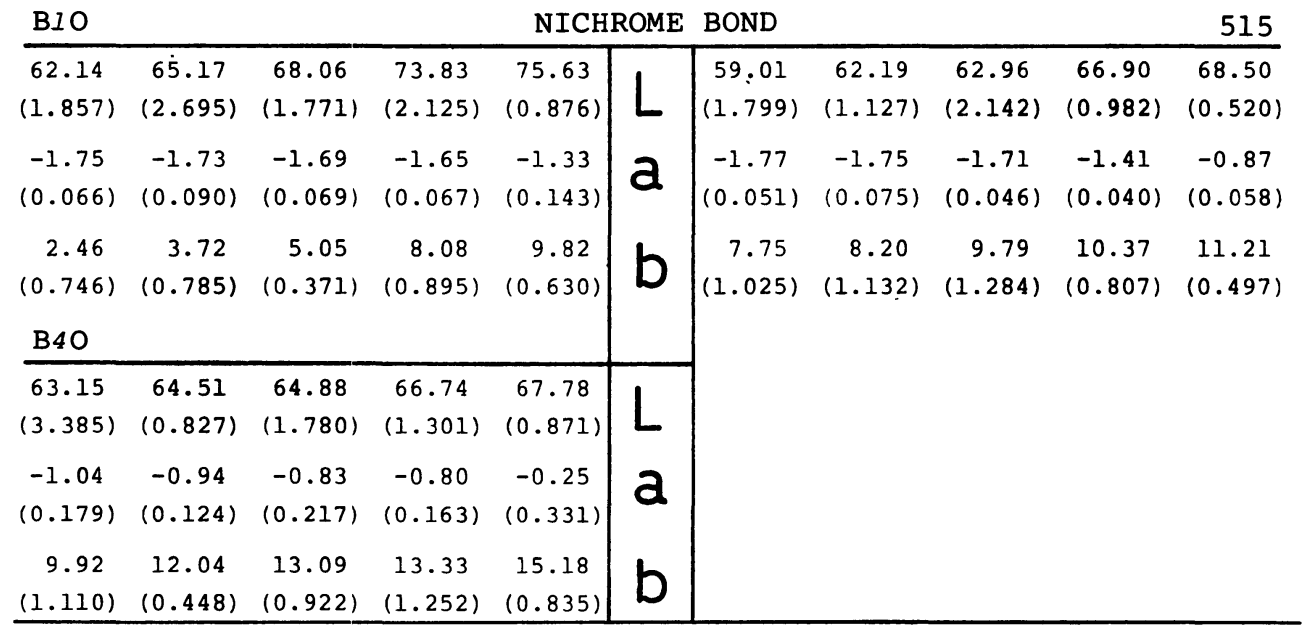

$$
\text { ( ) : } \pm \text { S. D. }
$$

and $b$ values when margin porcelain materials were fired on to the Nichrome bond. The $L$ values for $D_{3} M$ were variable under thin layer conditions, and the $L$ value of the other materials increased gradually as the layer thickness increased. Especially this tendency was remarkable in the case of $\mathrm{B}_{2} \mathrm{M}$ and $\mathrm{C}_{2} \mathrm{M}$. The a values of the margin porcelains tended to indicate a slight green. The $b$ values showed no remarkable changes even if the layer thickness of the margin porcelain was increased. The $b$ values tended to indicate a yellow 


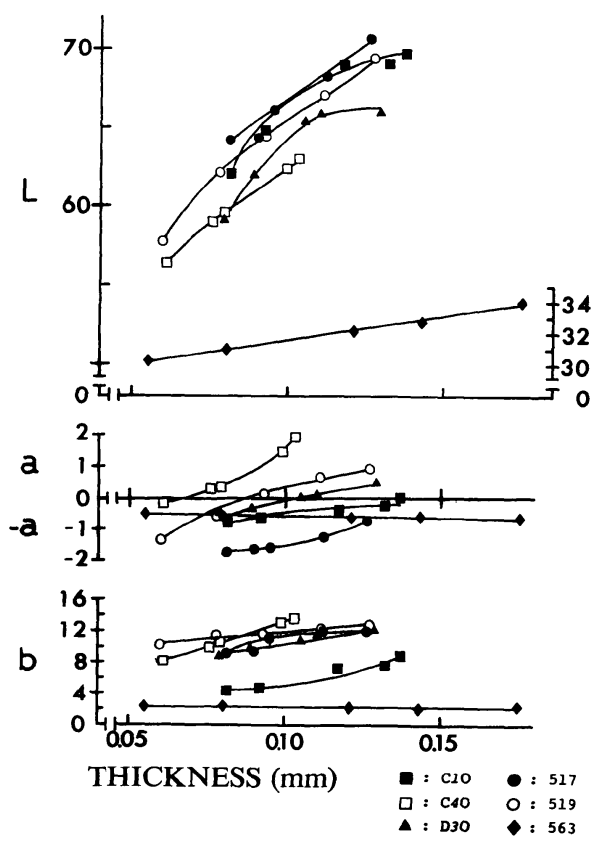

Figure 11 Relationship between porcelain thickness and $\mathrm{L}, \mathrm{a}$, and $\mathrm{b}$ values when $\mathrm{C}_{1} \mathrm{O}, \mathrm{C}_{4} \mathrm{O}, \mathrm{D}_{3} \mathrm{O}, 517,519$, and 563 porcelain materials were fired on to the Nichrome bond alloy.

Table 13 Measured values for $\mathrm{L}$, a, and $\mathrm{b}$ when $\mathrm{C}_{1} \mathrm{O}, \mathrm{C}_{4} \mathrm{O}, \mathrm{D}_{3} \mathrm{O}, 517,519$, and 563 porcelain materials were fired on to the Nichrome bond alloy

\begin{tabular}{|c|c|c|c|c|c|c|c|c|c|c|}
\hline $\mathrm{ClO}$ & & & & NICHF & ROME & BOND & & & & 517 \\
\hline 62.10 & 64.88 & 69.17 & 69.19 & 69.93 & & 64.23 & 64.40 & 66.24 & 68.41 & 70.82 \\
\hline$(1.932)$ & $(1.069)$ & $(0.840)$ & (1.481) & $(1.353)$ & & $(2.406)$ & $(1.838)$ & $(0.794)$ & $(0.463)$ & $(1.474)$ \\
\hline-0.75 & -0.61 & -0.32 & -0.24 & 0.06 & & -1.70 & -1.56 & -1.54 & -1.22 & -0.73 \\
\hline$(0.069)$ & $(0.081)$ & $(0.194)$ & $(0.072)$ & $(0.214)$ & & $(0.070)$ & $(0.087)$ & $(0.147)$ & $(0.047)$ & $(0.145)$ \\
\hline 4.56 & 4.70 & 7.30 & 7.57 & 8.92 & & 9.38 & 9.40 & 11.42 & 12.26 & 12.46 \\
\hline$(0.598)$ & $(1.052)$ & $(0.684)$ & $(0.383)$ & $(0.927)$ & & $(0.721)$ & $(0.766)$ & $(1.027)$ & $(0.223)$ & $(0.977)$ \\
\hline $\mathrm{C} 4 \mathrm{O}$ & & & & & & & & & & 519 \\
\hline 56.53 & 59.11 & 59.68 & 62.61 & 62.89 & & 57.80 & 62.21 & 64.46 & 67.06 & 69.43 \\
\hline$(1.296)$ & $(1.888)$ & $(0.651)$ & $(1.382)$ & $(0.987)$ & & $(0.738)$ & $(1.121)$ & $(1.164)$ & $(0.709)$ & $(0.743)$ \\
\hline-0.14 & 0.31 & 0.35 & 1.45 & 1.93 & & -1.31 & -0.49 & 0.12 & 0.67 & 0.94 \\
\hline$(0.121)$ & $(0.281)$ & $(0.198)$ & $(0.322)$ & $(0.458)$ & & $(0.087)$ & $(0.220)$ & $(0.322)$ & $(0.236)$ & $(0.201)$ \\
\hline 8.20 & 10.06 & 10.58 & 13.11 & 13.53 & & 10.28 & 11.68 & 11.69 & 12.22 & 12.48 \\
\hline$(0.226)$ & $(1.153)$ & $(0.531)$ & $(0.868)$ & $(0.705)$ & & $(0.541)$ & $(0.587)$ & $(0.601)$ & $(0.676)$ & $(0.317)$ \\
\hline D30 & & & & & & & & & & 563 \\
\hline 59.10 & 62.09 & 65.55 & 65.90 & 65.98 & & 30.20 & 30.94 & 32.08 & 32.71 & 34.01 \\
\hline$(1.167)$ & $(3.448)$ & $(1.756)$ & $(1.302)$ & $(0.656)$ & & $(0.778)$ & $(0.993)$ & $(0.534)$ & $(0.902)$ & $(0.621)$ \\
\hline-0.48 & -0.32 & 0.01 & 0.11 & 0.47 & & -0.53 & -0.58 & -0.62 & -0.63 & -0.66 \\
\hline$(0.169)$ & $(0.218)$ & $(0.169)$ & $(0.331)$ & $(0.116)$ & & $(0.087)$ & $(0.110)$ & $(0.059)$ & $(0.070)$ & $(0.060)$ \\
\hline 8.81 & 9.90 & 10.80 & 11.65 & 12.06 & & 2.22 & 2.31 & 2.32 & 2.35 & 2. 48 \\
\hline$(0.732)$ & $(0.938)$ & $(0.784)$ & $(0.658)$ & $(0.569)$ & & $(0.123)$ & $(0.093)$ & $(0.084)$ & $(0.162)$ & $(0.093)$ \\
\hline
\end{tabular}



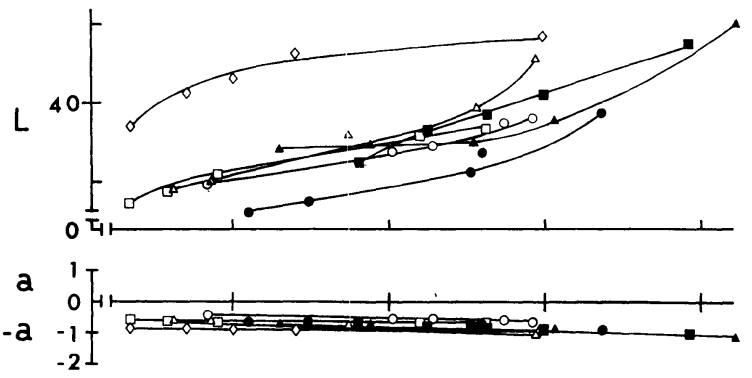

b

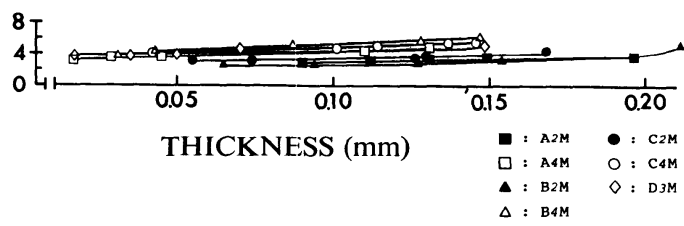

Figure 12 Relationship between porcelain thickness and $L, a$, and $b$ values when margin porcelain materials $\left(\mathrm{A}_{2} \mathrm{M}, \mathrm{A}_{4} \mathrm{M}, \mathrm{B}_{2} \mathrm{M}, \mathrm{B}_{4} \mathrm{M}, \mathrm{C}_{2} \mathrm{M}\right.$, $\mathrm{C}_{4} \mathrm{M}$, and $\mathrm{D}_{3} \mathrm{M}$ ) were fired on to the Nichrome bond alloy.

Table 14 Measured values for $L$, $a$, and $b$ when margin porcelain materials $\left(A_{2} M, A_{4} M\right.$, $B_{2} M, B_{4} M, C_{2} M, C_{4} M$, and $D_{3} M$ ) were fired on to the Nichrome bond alloy

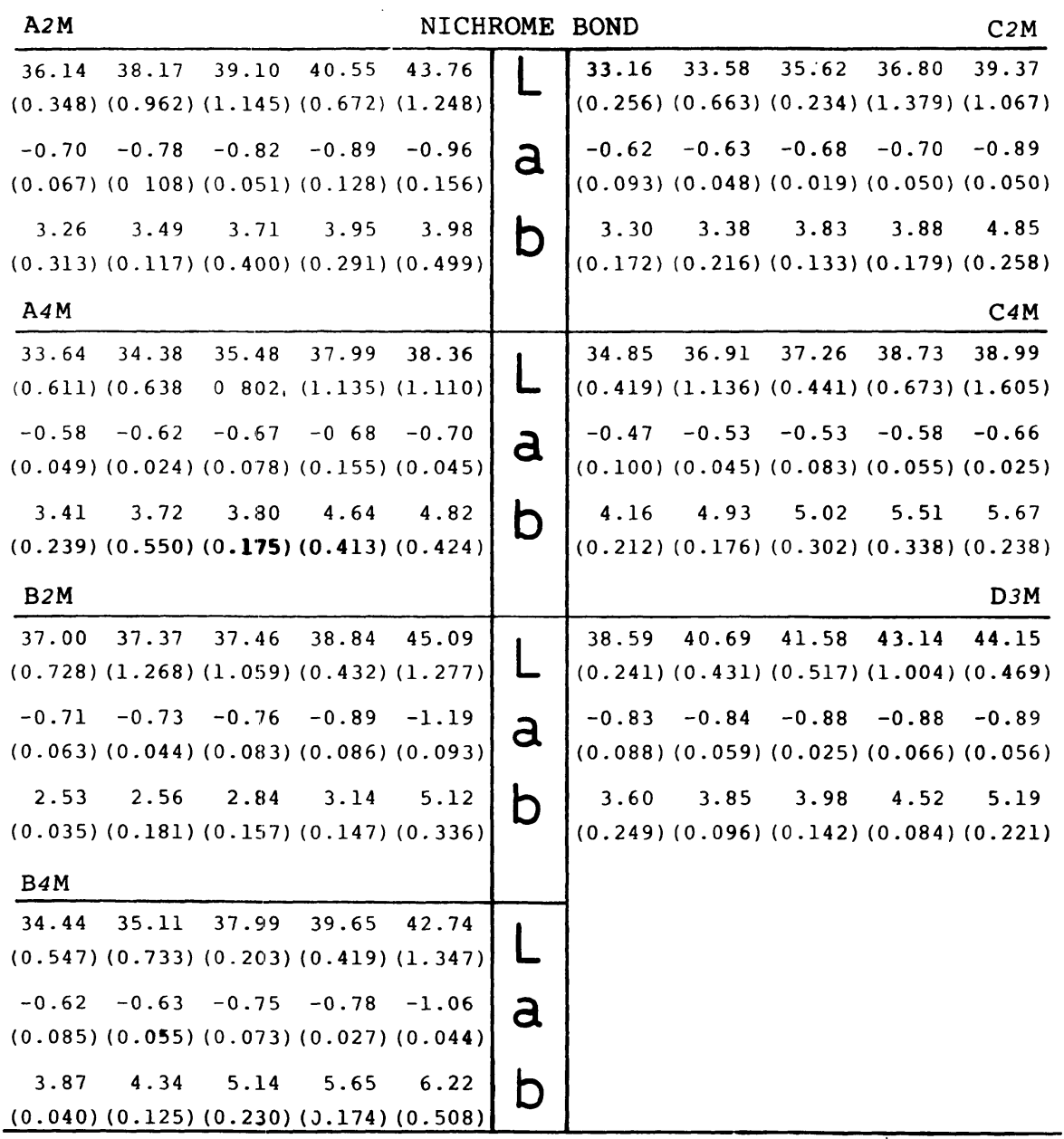


color in all cases.

Since the color aesthetics of porcelain bond crowns are adversely affected by a reduced film on the non-precious alloy surface, the opaque porcelain layer covering method ${ }^{14)}$ with was used. However as the opaque porcelain layer was unnecessarily thicker, the other porcelain layer became thinner, and the proper expressions of transparency and color tone became more difficult to achieve. For this reason, a bright and non-chromatic for the nonprecious alloy surface is desirable. ${ }^{12}$ Concerning the $\mathrm{L}$ values of the non-precious alloy surfaces, Bio cast, treated by firing with a bonding agent, was 35.44 (3.614), which was lower than the $47.76(0.182)$ of Uni metal and the $49.40(0.311)$ of Nichrome bond. However the $\mathrm{L}$ values for porcelain materials fired on to the Bio cast were generally higher under thin layer conditions. Especially this tendency was true in the case of $\mathrm{A}_{1} \mathrm{O}, \mathrm{B}_{1} \mathrm{O}$, and $\mathrm{C}_{1} \mathrm{O}$.

Generally $\mathrm{L}$ values are lowered by the production of $\mathrm{NiO}, \mathrm{Cr}_{2} \mathrm{O}_{3}, \mathrm{NiO} \cdot \mathrm{Cr}_{2} \mathrm{O}_{3}, \mathrm{NiO}$. $\mathrm{MoO}_{3}$ and $\mathrm{Mn}_{3} \mathrm{O}_{4}$ during firing. And $\mathrm{a}$ and $\mathrm{b}$ values are also lowered, and the color tone is expressed from dark blue to dark green. When $2 \%$ Beryllium was added to $\mathrm{Ni}-\mathrm{Cr}$ alloys, ${ }^{13)}$ the $\mathrm{L}$ value for this non-precious metal tended to be slightly low, and the $\mathrm{a}$ and $\mathrm{b}$ values indicated a gray color. These results demonstrated that Beryllium controls the production of Chromium and Nickel oxide film. On the other hand, in the case of Co-Cr alloys, the b value was decreased, indicating a light blue color, from the firing process of opaque porcelain materials; and it was increased, indicating a light brown color, from the firing process of Body porcelain materials. ${ }^{12}$ Also Bio cast (Co-Cr system) was reduced by Aluminum in the bonding agent (as formula (1) shows). Metal surfaces treated by bonding agent undergo the following reactions:

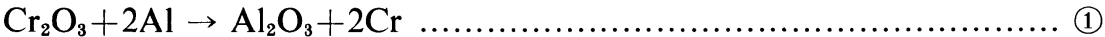

$$
\begin{aligned}
& \mathrm{Al}_{2} \mathrm{O}_{3}+\mathrm{K}_{2} \mathrm{O} \cdot \mathrm{Na}_{2} \mathrm{O} \cdot \mathrm{SiO}_{2} \rightarrow \mathrm{K}_{2} \mathrm{O} \cdot \mathrm{Na}_{2} \mathrm{O} \cdot \mathrm{Al}_{2} \mathrm{O}_{3} \cdot \mathrm{SiO}_{2} \quad \ldots \ldots \ldots \ldots \ldots \ldots \ldots . . . \ldots \ldots \text { (2) } \\
& 2 \mathrm{Cr}+3 / 2 \mathrm{O}_{2}+\mathrm{K}{ }_{2} \mathrm{O} \cdot \mathrm{Na}_{2} \mathrm{O} \cdot \mathrm{SiO}_{2} \rightarrow \mathrm{Cr}_{2} \mathrm{O}_{3} \cdot \mathrm{K}_{2} \mathrm{O} \cdot \mathrm{Na}_{2} \mathrm{O} \cdot \mathrm{SiO}_{2} \quad \ldots \ldots \ldots \ldots \ldots \text { (3) }
\end{aligned}
$$

This is recognized to be the mechanism which produces the minimum $\mathrm{Cr}_{2} \mathrm{O}_{3}$ necessary to combine with alloy and porcelain materials. The oxide, $\mathrm{Al}_{2} \mathrm{O}_{3}$, combines with silicate $\left(\mathrm{K}_{2} \mathrm{O} \cdot \mathrm{Na}_{2} \mathrm{O} \cdot \mathrm{SiO}_{2}\right)$, as shown in formula (2). Reduced Chromium is eliminated from the alloy surface, combines with the silicate of the bonding agent, and becomes a colored film, as shown in formula (3). From this point of view, the alloy surface treated with bonding agent is considered to combine well with porcelain materials because the elements $-\mathrm{K}_{2} \mathrm{O}$, $\mathrm{Na}_{2} \mathrm{O}, \mathrm{SiO}_{2}$ - are similar to the porcelain materials for bonding. ${ }^{15,16)}$ As the formation of these elements is similar to that of porcelain materials, the degree of light reflection is similar between them, and the $\mathrm{L}$ value becomes high even if the porcelain layer is thin.

\section{CONCLUSIONS}

We investigated by color analysis the effects of covering oxide films in non-precious alloys (Bio cast of the $\mathrm{Co}-\mathrm{Cr}$ system, Uni metal of the $\mathrm{Ni}-\mathrm{Cr}-\mathrm{Be}$ system, and Nichrome bond of the $\mathrm{Ni}-\mathrm{Cr}$ system) by firing with varying thicknesses of opaque porcelain materials and margin porcelain materials.

The results are as follows:

(1) The $\mathrm{L}$ value of the Bio cast treated with bonding agent was 35.44 (3.614). This 
value was lower than those for the other two alloys. But the $\mathrm{L}$ value of the porcelainfired Bio cast was high even under thin layer conditions in all cases. Especially this tendency was remarkable in the case of $\mathrm{A}_{1} \mathrm{O}, \mathrm{B}_{1} \mathrm{O}$, and $\mathrm{C}_{1} \mathrm{O}$.

(2) There were no remarkable differences in the a value of porcelain materials fired on to three kinds of non-precious metal alloys. $\mathrm{A}_{1} \mathrm{O}, \mathrm{B}_{1} \mathrm{O}$, and 563 fired on to the Bio cast and Uni metal and $\mathrm{A}_{1} \mathrm{O}$ and 563 fired on to the Nichrome bond tended to indicate a slight green color as the porcelain thickness was increased. The other porcelains tended to change from slightly green to non-chroma.

(3) The $L$ values for margin porcelain materials tended to increase as their thickness was increased. But this tendency was less than in the case of porcelain materials. The a values for porcelains fired on to the Bio cast were nearly non-chromatic even if the thickness was increased, and there was no difference.

(4) From analysis of the L and b values, a covering thickness of only $0.08-0.09 \mathrm{~mm}$ was found necessary to provide the desired color tone on oxide films of non-precious alloys.

\section{REFERENCES}

1) Yoshiharu Nakagawa, Takao Maruyama, Takaji Simoosa: Studies on Shade Selection in Porcelain Prosthesis Part 1. A sectional analysis of various shade guides; J.J.P.S, 16: 144-157, 1972, (in Japanese).

2) Akira Yoshida: Colorimetric Studies on Porcelain; J.J.P.S, 16: 245-267, 1972, (in Japanese).

3) Yoshiharu Nakagawa, Takao Maruyama, Takaji Simoosa: The Colorimetric Study of Porcelain fused to Metal Crown Metallic Color Changes under Porcelain fused Temperatures; J.J.P.S, 16: 350357, 1972, (in Japanese).

4) Yoshiharu Nakagawa: Studies on the Analysis of Tooth Color; J.J.P.S, 19: 109--130, 1975, (in Japanese).

5) Naomichi Nishida, Iwao Sakan, Kouichi Hashimoto, Hiroshi Yagengi, Akira Yoshida, Takao Maruyama, Takaji Simoosa: The Colorimetric Study on Gingiva Part 1. Influence of the Colorimetrical Conditions and the Environment; J.J.P.S, 19: 131-137, 1975, (in Japanese).

6) Kazuyoshi Uruta, Yoshimi Koshihara, Yoshio Ohta: A Chromatic Study of Porcelain (Part 2); J.J.P.S, 10: 173-181, 1976, (in Japanese).

7) Naomichi Nishida, Iwao Sakan, Kouichi Hashimoto, Hiroshi Yagenji, Akira Yoshida, Takao Maruyama, Takaji Simoosa, Yoji Murayama, Yoshio Nomura: The Colorimetric Study on Gingiva Part 3. The Influence of Porcelain-fused-to-Metal Crown on Gingiva; J.J.P.S, 20: 258-268, 1976, (in Japanese).

8) Masumi Ibusuki, Aiko Kato: Color of Maxillary First Premolars by Visual Color Matching; J.J.P.S, 20: 269-274, 1976, (in Japanese).

9) Aiko Kato: Color Arrangement in Upper Anterior Teeth; J.J.P.S, 20: 570-584, 1976, (in Japanese).

10) Yoshikazu Watanabe: The prognosis of porcelain crown and porcelain-baked crown; The Nippon Dental Review, 413: 85-93, 1977, (in Japanese).

11) Sumio Seki: The Histopathological and Electron-microscopical Study of the Gingival Discoloration Affected by the Fixed Prosthesis; J.J.P.S, 25: 368-380, 1981, (in Japanese).

12) Takashi Horibe, Yoshizo Okamoto, Yusuke Inoue, Tomoji Matuura, Koichi Nagaoka, Tuyoshi Miyaguchi, Shinichi Ukon: Studies on Color Analysis of Dental Porcelain Part 1. Color Analysis of the Surface of Dental Non-Precious Alloy by a Porcelain Firing Schedule; J. Fukuoka D.C., 9: 695-702, 1983, (in Japanese).

13) Yusuke Inoue, Yoshizo Okamoto, Takashi Horibe, Tomoji Matsuura, Koichi Nagaoka: Electron Probe Micro Analysis and Atomic Absorption Analysis on Non-precious Alloys for Metal-Porcelain Systems; J. J. Dent. Mat., 2: 140-143, 1983, (in Japanese).

14) Takashi Horibe, Yoshizo Okamoto, Kazuhiro Suenaga: The some physical characters and the technical problems of $\mathrm{Co}-\mathrm{Cr}$ alloy for the porcelain veneers; The Journal of Dental Technics, 9: 337352,1981 , (in Japanese). 
15) Yoshizo Okamoto: X-ray Fluorescence Analysis of the Porcelains for Dental Veneering; J. Fukuoka D. C., 7: 261-268, 1980, (in Japanese).

16) Yoshizo Okamoto: On the Physicochemical Characters of the Porcelains for Dental Veneering; J. J. Dent. Mat., 1: 138-171, 1982, (in Japanese). 
短時間内に進行し終結するととがわかった。このように 硬化特性からみても，かなり性格の異なるアロイが同時
に多数市販されているので, 臨床的な使用に際しては注 意が必要であるととがわかった。

焼付用陶材の色彩分析について

II.オペーク陶材の舟金属合金への遮蔽効果

岡本佳三, 堀部 隆, 井上勇介

松浦智二*, 長岡幸一*

福岡歯科大学歯科理工学教室

*福岡歯科大学第 2 補経学教室

焼付用卑金属合金 ( $\mathrm{Co}-\mathrm{Cr}$ 系 Bio cast, $\mathrm{Ni}-\mathrm{Cr}-\mathrm{Be}$ 系 Uni metal, Ni-Cr 系 Nichrome bond) 三種類に, オ ペーク陶材 (Uni bond 7 種, Vita VMK 68 Paint-on 886 種)とマージン陶材 7 種の層厚を変化させて焼付け, 陶材の厚みの变化による酸化被膜の遮蔽効果を色彩分析 で検討したところ，Bio castに築盛哇成した陶材は薄層 においても全体的にL 值が高く, 特に $\mathrm{A}_{1} \mathrm{O}, \mathrm{B}_{1} \mathrm{O}, \mathrm{C}_{1} \mathrm{O}$ にこの傾向が著しく表われた。Bio cast および Uni metal
に烍成した $\mathrm{A}_{1} \mathrm{O}, \mathrm{B}_{1} \mathrm{O}, 563$ と, Nichrome bond に焼成 した $\mathrm{A}_{1} \mathrm{O}, 563$ は, 陶材の厚さが増すにつれて, 緑色傾向 が強くなり, 他陶材は緑色傾向から無彩色への変化が見 られた。マージンポーセレンは, 厚さの増加によってL 值が大きくなったが, 他の陶材に比べてわずかの変動で あった。L值および $\mathrm{b}$ 值より, 燒付用龵金属合金の酸化 被膜の遮蔽および色調再現效果は，0.08 0.09 mm あ れば十分にその効果が表われるものと思われる。

\section{パラシウムを含む市販金合金の時効硬化 \\ 安田克廣, 有働公一, 久恒邦博, 太田道雄* \\ 長崎大学歯学部歯科理工学教室 \\ *九州大学歯学部歯科理工学教室}

Pd を含む市販 $16 \mathrm{~K}, 14 \mathrm{~K}$ 金合金の時効硬化機構を 明らかにするため, 電顕直接観察，X線および電子線回 折を行った。

1）時効過程は f.c.c. 不規則固溶体 $\rightarrow$ 準安定 $\mathrm{AuCuI}^{\prime}$ 規則格子相 $\rightarrow$ 平衡相 $\mathrm{AuCuI}$ 規則格子相 $+\mathrm{Ag}-$ rich $\alpha_{2}$ 相 (f.c.c) であった。

2) $\mathrm{AuCuI}^{\prime}$ 相は時效初期にマトリックス中の $\{100\}$ に平行に形成され，正方晶化にとあなうひずみを軽減す るために $\mathrm{C}$ 軸は〈100〉に沿う 3 方向に分布した。時効
硬化の主要な原因は $\mathrm{AuCu} \mathrm{I}^{\prime}$ 板状相の〔001]方向のひ ずみ場であった。

3) $\mathrm{AuCuI}$ 相は $\alpha_{2}$ 相と共に結晶粒界からラメラ構 造となって粒内に成長し, 同時に $\mathrm{AuCu} \mathrm{I}^{\prime}$ 相は消失し た。ラメラの界面は非整合と考えられ, 硬化の原因とな るひずみは観察されなかった。

4）長周期構造を持つ $\mathrm{AuCu}$ II 型規則格子相は本実 験では観察されなかった。

$\mathrm{X}$ 線光電子分析 (ESCA) とよる陶材焼付用金合金の酸化表面の解析

$$
\text { 大野弘機, 神澤康夫, 山根由朗 }
$$

東日本学園大学菌学部菌科理工学教室

陶材焼付用金合金一85. $5 \mathrm{Au}, 6 \mathrm{Pt}, 6 \mathrm{Pd}, 1 \mathrm{Ag}, 0.6$ Sn, $0.9 \mathrm{In}(\mathrm{wt} \%)$-を $1000^{\circ} \mathrm{C}$, 大気中で $30 \mathrm{sec} \sim 60 \mathrm{~min}$
加熱し, その酸化表面を ESCA で解析した。その結果, 加熱時間にかかわりなく, Au (4f), Pt (4f), Pd (3d) 